This item was submitted to Loughborough's Research Repository by the author.

Items in Figshare are protected by copyright, with all rights reserved, unless otherwise indicated.

\title{
Decivilizing, civilizing or informalizing? The international development of Mixed Martial Arts
}

PLEASE CITE THE PUBLISHED VERSION

http://dx.doi.org/10.1177/1012690209352392

PUBLISHER

SAGE @ The Author(s)

VERSION

AM (Accepted Manuscript)

LICENCE

CC BY-NC-ND 4.0

\section{REPOSITORY RECORD}

Garcia, Raul Sanchez, and Dominic Malcolm. 2019. "Decivilizing, Civilizing or Informalizing? the International Development of Mixed Martial Arts". figshare. https://hdl.handle.net/2134/15317. 
This item was submitted to Loughborough's Institutional Repository (https://dspace.lboro.ac.uk/) by the author and is made available under the following Creative Commons Licence conditions.

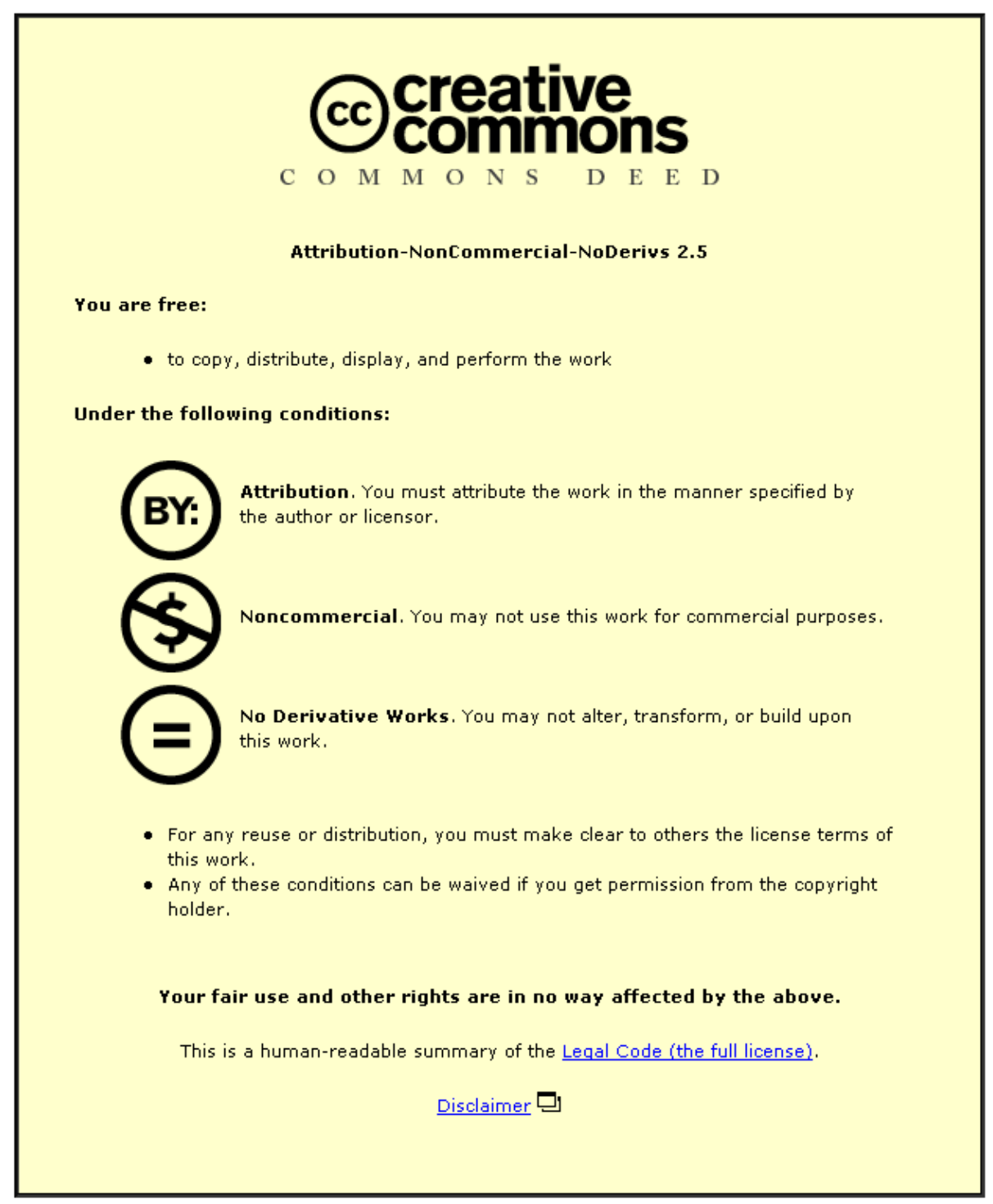

For the full text of this licence, please go to: http://creativecommons.org/licenses/by-nc-nd/2.5/ 


\section{De-civilizing, Civilizing or Informalizing? The International Development of Mixed Martial Arts}

As van Bottenburg and Heilbron (2006) note, there has been a surprising lack of interest in the emergence of the combat activities we might broadly term mixed martial arts (MMA). This limited analysis has largely been informed by figurational sociology and focussed on the relationship between MMA and Elias's theory of civilizing processes (1994). A range of interpretations exist: that the development of mixed combat disciplines either provides supporting evidence for (Sheard, 1992; 1998a; Howes 1998), or a refutation of, Elias’s theory of civilizing processes (Sugden, 1996); or alternatively, in that MMA exhibits evidence of barbarization and de-sportization processes, its development exposes some limitations in Elias’s work on sportization (van Bottenburg and Heilbron 1997, 2006). This article addresses the specific issue of trends in violence in combat sports and in so doing contributes to on-going debates about figurational sociology. More specifically, we draws on the work of Wouters (1986; 2004) and Elias and Dunning (1986) to propose an alternative interpretation of the rise of MMA; that is to say, that it illustrates processes of both informalization and the quest for excitement.

The empirical data presented in this paper were gathered through content analysis of martial arts journals (Dojo, Budoka, Fightsport, Crosscombat) and websites, and the literature written by (or ghosted for) MMA insiders. During the course of a broader research project (Sanchez Garcia, 2006) the first named author also conducted semistructured interviews and informal conversations with practitioners from several combat sports, and took part in various boxing, kick-boxing and aikido training and competition, though these data are not presented here. 


\section{Mixed Martial Arts}

The term MMA is used to describe sport activities based on the combination of bare handed (as opposed to with weapons) oriental martial arts and Western combat sports. The most common forms of MMA are called Ultimate Fighting Contest (UFC), Pride and K-1. Broadly speaking MMA refers to any activity which entails an amalgam of unarmed combat styles though different forms of MMA place different emphases on the specific combination of standing striking techniques (from disciplines such as boxing, karate, kick-boxing, kung-fu, taekwondo, thai-boxing, savate) and grappling techniques and fighting on the ground (from disciplines such as judo, Greco-Roman wrestling, sambo or Brazilian jiu-jitsu). Bouts are decided by knockout or submission.

A central rationale behind the initial development of MMA was the desire to see which fighting discipline was the most effective. It remains the case that fighters tend to come to MMA from a particular disciplinary background and particular MMA teams are often known for being centred on different techniques (e.g Chute Boxe and standing striking, Team Quest and wrestling, and Brazilian Top Team and jiu-jitsu), ${ }^{1}$ but as MMA has became more established, its proponents have tended to become more rounded fighters, training in those areas in which they are weakest and leading to a hybridization of fighting styles. Contemporary MMA champions have a broad range of skills encompassing a number of combat disciplines. As Mark Kerr, a prominent MMA fighter has stated, 'I always said that the future fighter is a decathlete. He can't be closed minded about styles or training methods. He needs to combine different styles and methods and find his own way to deliver techniques. He must find his own perfect combination of elements and techniques' (Fraguas, 2003: 179). In contemporary MMA it therefore makes sense to talk of fighters who have different strengths or approaches 
rather than fighters from different disciplines. The merger between American UFC and Japanese Pride in 2007, with a shared set of competition rules, has facilitated the interchange of techniques and standardization of contests.

Although the terms are sometimes used as synonyms, MMA should be seen as distinct from No Holds Barred (NHB) contests. NHB was the English term used in the early days of MMA - particularly during the 1990s - and derived from the translation of the Portuguese term vale-tudo (anything goes). However, the term NHB is more indicative of the strong connection between American MMA's main organization (UFC) and its Brazilian roots (more on this later on), than it is of unregulated fighting. UFC was always more rule-bound than its Brazilian predecessor, even though publicity for UFC events has not always accurately portrayed this.

\section{Informalization and the Quest for Excitement}

Wouters' concept of informalization derives from his analysis of the so-called permissive society of the 1960s. Wouters (1986) notes that the relaxation of social regulation (e.g. with regard to sex and nudity) and the development of less formal social relations evident in the 1960s (e.g. the more flexible interpretation of manners and the questioning of status hierarchies), was interpreted by some as a moral decline of society; as de-civilizing in the everyday sense of that term. Wouters argues, however, that these behavioural changes are not indicative of a de-civilizing process in Elias's technical sense but, rather, represent a complex and highly differentiated form of civilizing process. The increasing social equality (between the sexes, classes and generations) characteristic of the permissive society entailed diminished contrasts in behaviour which were expressed in an increasing variety of (moderate) ways. There is, 
however, a significant illusory aspect to the trend towards individualization and the rejection of social codes 'imposed' by society. Whilst people are increasingly enabled to question why they should conform, and have greater licence to submit to their emotional and libidinal urges, this freedom occurs in conjunction with a strong compulsion to more consciously reflect upon their own actions, and thus behaviour is characterized by heightened levels of self-restraint. Wouters identifies a balance between formalizing and informalizing trends within the civilizing process where, respectively, behavioural control is more explicit and externally imposed, and where it is more implicit and internally driven. Wouters (2004) further argues that whilst the predominant trend in Europe since the Middle Ages has been towards formalization, the process is better characterized as a series of informalization and reformalization waves and counter waves. Elias identified internalized forms of social control and the heightened use of fore-thought as central characteristics of civilizing processes and thus Wouters' work should be considered an expansion, rather than reformulation, of Elias's theory.

The quest for excitement thesis, like informalization, is an extension of Elias's theory of civilizing processes. In Quest for Excitement, Elias and Dunning (1986) sought to outline the relationship between the historically specific physical contests of contemporary societies and the broader structure of those societies. In attempting to account for the social significance of sport and leisure, Elias and Dunning distinguish between 'real life' and 'mimetic' excitement. Real life excitement may be generated in critical or dangerous situations (e.g. natural disasters, attack from animals or other humans) but in modern societies opportunities for unreflective expressions of real life excitement are limited. Consequently, there develops a socially conditioned, 
psychological need for pleasurable excitement and thus the role of mimetic excitement becomes more prominent. Mimetic excitement is the 'sibling' of the excitement generated in 'real life' situations, similar in kind but lacking the more extreme danger posed in 'real life'.

In relation to sport, the process of sportization in which pastimes become codified, standardized and increasingly regulated, leads sports in contemporary societies to become 'mock fights' or substitutes for 'real life' combat (Elias, 1986). For Elias (1986), modern sports are distinguished from their folk antecedents by the use of more precise and explicit rules, which are written down and more formally and strictly enforced. Because rules invariably restrict the means by which individuals can achieve sporting success, sportization necessarily entails the development of stricter self-control and self-discipline amongst participants, and thus a 'civilizing spurt'. Whilst Elias (1986) related sportization to the parallel process of parliamentarization, he did not attribute causation to one or the other. Both occurred as part of a wider civilizing process, being 'two manifestations of a set of broader changes that occurred at the levels of "social structure” and "personality structure” or habitus” (Malcolm, 2005: 116).

As activities are sportized, the role of mimetic excitement becomes increasingly significant. Participants and spectators experience the mimetic excitement of battle safe in the knowledge that the potential for 'real' harm is small. Central to the popularity of sport in modern societies is the 'tension balance' (Elias and Dunning, 1966: 397) such activities generate for both players and spectators; that is to say, the balance of danger and safety, freedom and restraint. Modern leisure activities, and sports in particular, are socially significant because they provide some of the relatively few opportunities for a 
'controlled de-controlling of emotional controls' in contemporary societies. Indeed participants in combat sports explicitly recognize the differences between the 'mock fights' for which they train and 'real fighting'. The latter term is reserved for unregulated combat such as streetfighting (Wacquant, 1995: 498), and is used here to recognize the qualitative differences combat sportspeople identify between these activities rather than to portray the fighting in combat sports as 'unreal'.

This paper argues that the growth of MMA is indicative of an informalization process, and that the developmental stages so far evident illustrate oscillations in the search for an appropriate tension balance in the initial stages of a sportization process. These oscillations stem from the intended and unintended consequences of the actions of various and competing actors. Whilst, as identified by van Bottenburg and Heilbron (2006), heightened levels of violence were evident during the earlier stages of MMA's formation, the longer term combination of the more flexible application of a greater number of combat techniques without a concomitant increase in the level of harm to participants, suggests that the development of MMA has been underpinned by heightened levels of self-control and sensitivity towards inflicting physical harm. Because the popularity of modern sport depends on the generation of pleasureable mimetic excitement, MMA promoters have responded to pacifying pressures with a combination of violence reducing rule changes and spectacularized violence.

\section{The International Development of Combat Sports in the Twentieth Century}

The development of combat sports during the twentieth century was broadly structured by tensions between amateurism and professionalism and between Eastern and Western fighting styles. While the former tension has been resolved by the ascendancy of professionalism, the latter has resulted in hybridization. 
Eastern and Western combat disciplines initially developed relatively autonomously of each other. The first cultural commingling took place from around the end of the nineteenth century, with the opening of Japan to the West in the Meiji Restoration. Westerners became increasingly exposed to Japanese disciplines such as judo and kendo (Hlinak, 2009; Law, 2008; Svinth, 2003a), and, largely due to the activities of Westerners in merchant navies, the Japanese became increasingly exposed to Western sports forms such as boxing (Svinth, 2003b).

Such early interchanges belie the roots of the interest in the relative valence of different fighting techniques which was central to the initial emergence of MMA. It was in this context that many jiu-jitsu and other martial artists taught their techniques and sometimes displayed their skills in organized competitions against Western boxers or wrestlers (Green and Svinth, 2003: 61-62). Similarly, American merchant sailors coming to Japan took part in contests called 'Merikan' (from the term 'American'), where boxers was pitted against local fighters under special rules (Svinth, 2003b: 3739). Whilst we can see the antecedents of MMA in these contests, they were largely seen as exhibitions rather than genuine sporting encounters or challenges between fighting disciplines.

The European and amateur hegemony in (combat) sport at this time was exemplified by the inclusion of boxing, wrestling and fencing in the amateur Olympic programme and the exclusion of judo, karate, etc. Whilst professional wrestling experienced something of a golden age in the music halls of Europe and the USA between 1900 and 1914 (Kent, 1969: 146), increasingly it became seen more as (staged) entertainment and thus 
less prestigious in sporting terms (Beekman, 2006). Professional boxing, with its sporting (i.e. competitive) credentials intact, overtook professional wrestling in terms of popularity and, in line with the ascendancy of professional sport more generally, became the world's premier combat sport (Fleischer et al., 1981). Amateur combat sports have traditionally maintained a greater distance from 'real fighting' than their professional counterparts through the more extensive use of protective equipment (gloves, helmets, plate guards) and restrictive rules (legitimate strike areas, shorter rounds, more interventionist role for referees). Conversely professional combat sports have more intense physical contact, less protective equipment, and a greater emphasis on knockouts (Estwanik, 1995).

The hybridization of Asian and Western disciplines started in the 1960s. In line with the European amateur hegemony in international sport at this time, fighting contests were normally decided on the basis of judges' decisions rather than knockout or submission. Judges rewarded speed and technique rather than strength and aggression. Those with experience of combat training and sports forms closer to 'real fighting' (mainly American ex-combatants on the Asian front, and Japanese practitioners of certain 'hard' karate styles) perceived these contests to be too restrained and an inadequate test of fighting capabilities (Camps, 1990: 172). This particularly affected the striking martial arts disciplines. For instance, during the Third Karate World Championship in Long Beach, California in 1975, France’s Dominique Valera vigorously objected to being repeatedly penalized for the excessive power of his strikes and subsequently left the sport and took up 'Full Contact' karate (Camps, 1990). Whilst less problematic in grappling disciplines such as wrestling and judo where the application of strength 
remained relatively important, striking disciplines were regulated such that, for some, the activity ceased to be sufficiently 'real' to be exciting in the Eliasian sense.

For proponents of the striking martial arts disciplines the fusion of their own technical elements with aspects of professional boxing provided one solution. The US, undergoing a martial arts craze stimulated by Bruce Lee (who was himself a vehement defender of 'real fighting' combat), was a central location for this development. Full Contact karate and kick boxing grew in popularity in the US, with the first Full Contact Championship organized by Mike Anderson in Los Angeles in 1974 under the sanction of the Professional Karate Association (PKA). Anderson persuaded Universal Pictures to broadcast aspects of the Championship and thus from this point, Full Contact came under the influence of commercial interests (Perreca and Malori, 2000a:10).

Concurrently, kick boxing became more popular in Japan, stimulated by the techniques pioneered by Kenji Kurosaki, and the marketing and promotion of Osamu Noguchi. After competing in Thailand Kurosaki, a master of Kyokushinkai karate, incorporated Thai boxing techniques into his karate style (Di Marino, 2003: 6). Leading kickboxers from Japan and later Europe aspired to attend the workshops at his famous Mejiro Gym. Noguchi successfully built on Kurosaki's popularity by liaising with Thai and American promoters to stage the First World Kickboxing Championship.

In the mid 1970s, the World Karate Association (WKA), an American organization representing professional Full Contact fighters, succeded in combining the Japanese and American strands of these emerging sports forms. The WKA employed Japanese prowrestler Antonio Inoki, who had fought Muhammed Ali in a mixed discipline event in 
Tokyo in June 1976, to generate Japanese interest. From 1977 to 1979 several Full Contact kick boxing contests, combining traditional karate and kick boxing techniques were broadcast in the USA and Japan. Amateur karate organizations resisted these developments and, following the Karate World Congress held in London in 1980, the WKA was renamed the World Kickboxing Association (Perreca and Malori, 2000b:11). In Europe, Full Contact and kick boxing first became popular in the karate strongholds of France and Holland with the latter, aided by the popularity of Thai boxing figures such as Rob Kaman or Ramon Dekkers in the 1980s and 1990s, ultimately becoming the predominant form.

From the 1990s the mixing of techniques from different combat sports became more extensive and thus MMA could be said to have become properly formed. Full Contact and kick boxing were gradually superceded by Japanese K-1 (a standing form of mixed disciplines) and the more all-inclusive Ultimate Fight Championship (UFC) in the USA and PRIDE in Japan which combined floor and standing grappling with striking combat.

K-1 was borne out of the profusion of different karate styles which had Kyokushinkai karate as their common core (Brunekreef, 2007). Through competitions between different karate schools, and between karate and other martial arts (Thai and Birmanian boxing, wu-shu, kick boxing, etc.), Seidokan karate achieved global recognition. Consequently the karate tournaments organized by Seidokan karate's leading proponent, Master K. Ishii, became increasingly popular and internationally renowned. Following the successful staging of an international karate tournament in 1990, Ishii organized the First World Championship of Seidokan karate in 1992. K-1 emerged at the Second Championship in 1993. K-1 was predicated upon the desire to give standing 
striking disciplines relatively equal prominence within one event with the ' $\mathrm{K}$ ' of $\mathrm{K}-1$ corresponding to karate, kick-boxing, kempo, taekwondo and kung-fu (Cross Combat, 2004(5): 44).

Correlatively, UFC emerged in America when Rorion Gracie offered \$100,000 to any martial arts exponent who could defeat him. The Brazilian jiu-jitsu developed by the Gracie family attracted considerable public interest, which Semaphore Entertainment Group (SEG) exploited for the 1993 launch of UFC. With no weight categories, no time limit, victory only by knockout, submission or abandonment, and only strikes to the crotch and throat and eye-gouging forbidden, UFC was the most complete rejection of amateur combat styles. It was also reported to be popular with television audiences (Yokohama, 2006: 166).

Stimulated by the development of UFC, PRIDE emerged as a second form of Japanese MMA. Managed by Dream Stage Entertainment, PRIDE drew on the tradition of Japanese professional wrestling which had developed from the 1960s. Like American professional wrestling the outcome of Japanese wrestling was normally pre-arranged but, unlike American professional wrestling, combat was perceived to be 'real' and violent, incorporating Thai boxing, karate and ju-jutsu techniques. This style of fighting, also named shoot or shoot fighting (Snowden, 2008: 102-105), became known as Universal Wrestling Federation (UWF) in the 1980s, and RINGS, Pancrase or Japanese vale tudo in the 1990s.

K-1, UFC and PRIDE are now global events with tournaments broadcast by established sports channels such as Eurosport or CBS. International variants take different names, 
such as 'APEX' in Canada and 'Warrior's Realm' in Australia. The first official bout in Europe, the 'Cage Fight Tournament', was held in Belgium in 1995 (Fightsport, 2004(3): 22) and, whilst not successful in itself, stimulated sufficient Dutch interest to lead to the subsequent establishment of 'Free Fight Event' in Amsterdam and '2hot2handle' in Rotterdam. In England variants are called 'Cage Rage', 'King of the Cage' and 'Ultimate Combat', whilst 'Shooto' predominates in Sweden, Switzerland and Lithuania. 'Cage' in Finland, 'Viking Fight' in Denmark, 'Mix Fight M-1' in Russia, 'The Star of Peresvit' in Ukraine, '2hot2 handle Germany', 'K.O Arena' in Spain and 'Pankration' in Greece are other variants. Despite early interest in Full Contact and kick boxing, France is the only European country that prohibits MMA events. Table 1 shows the popularity and penetration of MMA throughout Europe.

\section{Insert Table 1 here}

Despite this international spread, and whilst Brazil's vale tudo tradition is globally considered a school of excellence for fighters, it is in the US and Japan that MMA is most popular. Whereas MMA competitions can gather around 6,000 fans in Dutch arenas (Fightsport, 2004(3): 23), over double this number (13,000) attended UFC 40 in the USA in 2002 and 5.1 million viewers watched the Ortiz-Shamrock UFC fight on Spike TV in 2006 (Snowden, 2008: 263). In Japan, however, some 71,000 attended the combined PRIDE-K-1 event called Shockwave 2002 or K-1 Dynamite in 2002 (Gentry, 2004: 245), 90,000 attended the K-1 Grand Prix in the National Stadium in Tokyo in the same year (Kerr, 2005: 117), and the 2004 PRIDE Grand Prix at Saitama Superarena in Tokyo attracted 50,000 spectators (Fightsport, 2004(1): 24). An estimated 54 million 
Japanese (almost half the population) followed the Bob Sapp-Akebono superfight in K1 during 2004 (Snowden, 2008: 282).

PRIDE and UFC had something of a Janus-faced relationship, having tried to infiltrate each others' markets and also having jointly staged events. The purchase of PRIDE by UFC promoters in 2007 has enabled the consolidation of MMA as a global sport, entailing the standardization of rules and the incorporation of smaller MMA variant promotions. As co-owner of UFC Lorenzo Fertitta has stated, this takeover, 'is really going to change the face of MMA. Literally, creating a sport that could be as big around the world as soccer. I liken it somewhat to when the NFC and AFC came together to create the NFL’ (quoted in Snowden, 2008: 315).

\section{MMA: Decivilizing or Civilizing?}

What are the implications of these developments for on going debates about the value of Elias's work? As noted in the introduction, some have interpreted the development of MMA as evidence of a de-civilizing process. Sugden (1996: 177), drawing on an account published in Sport, Fitness and Health magazine, argues that descriptions of UFC are 'very similar' to Elias's account of the Ancient Greek activity of Pankration. Van Bottenburg and Heilbron $(1997,2006)$ similarly suggest that the emergence of less precise, less explicit, and more localized and transitory rules illustrates the prominence of de-sportization processes in the development of UFC. In the development of UFC, they argue, 'technique and style were subordinated to the sensation that the fights had to offer as spectacles. This sensation was achieved by deliberately increasing the level of violence' (2006: 268. Emphasis in original). The central problem with each of these contentions is that they are predicated on an exaggerated portrayal of violence in 
UFC/NHB. A similar error is evident in broader public debates about MMA.

MMA is commonly perceived to be relatively violent because contests combine the most dangerous aspect of boxing - punches to the head - with a range of other offensive tactics (in both the attacking and transgressive senses), including kicks and knees to the body and head. Yet MMA also allows competitors to draw on the grappling techniques of combat sports perceived to be less violent than boxing, such as judo and wrestling. The balance between these different elements in the outcome of UFC matches is revealing of the overall levels of violence in MMA. Between 1993 to 1999, victories were most commonly achieved through a submission applied while on the ground (35.8\% of 176 matches). Other victories came through (hand) striking on the ground (24.4\%), (hand or foot) striking while standing (16.5\%), ${ }^{2}$ standing submission (2.3\%), and from throws (1\%). As Bolelli (2003: 46) notes, such findings conflict with stereotypical views of martial arts which centre on the use of standing kicks and punches. In mixing combat styles therefore, proponents have not necessarily prioritized those techniques widely considered to be relatively violent, but have found the less violent and more socially acceptable grappling techniques more effective. Similarly, in their analysis of injuries in MMA in Nevada over a three year period, Bledsoe et al. (2006: 140) conclude that, 'the opportunity to attack the extremities with arm bars and head locks and the possibility of extended periods of grappling could serve to lessen the risk of traumatic brain injury [relative to boxing]'.

The prevalence of submissions in UFC influences training and thus a fighter's overall exposure to violence. Some claim (reference) that one of the greatest potential dangers in boxing is the receipt of blows to the head when sparring in training. Leon Tabbs, who 
worked in boxing before becoming a cutman in UFC, has commented on the relative training requirements:

The UFC is not as brutal as boxing, and I say this because in preparing a fighter for a fight ... he’s boxing maybe six to eight rounds a day. At best, the headgear is stopping you from getting cut but the damage is still there. There's no question about it ... Boxing is so much worse as far as the amount of punishment a man takes (quoted in Gentry, 2004: 157).

In contrast to this, Amtmann (2004) notes that the majority of MMA fighters he surveyed participated in 'MMA specific training' just five or six times a week. This fight training, moreover, is divided between striking, standing grappling and floor grappling techniques. MMA therefore entails less continuous and sustained impact to the head in training than other striking combat sports.

Testimony from competitors also suggests that MMA participation entails a lower risk of injury relative to other combat events. Randy Couture, UFC superstar and former Olympic wrestler, has spoken of the comparison between MMA and other combat sports:

I think that it (MMA) is very safe ... I have seen much more serious injuries in Olympic Greco-Roman wrestling than in the six years I've been fighting here (in the UFC). Mainly I have seen cuts, bloody noses and things like that, a black eye from time to time, but I have not seen dislocated joints or broken bones as I have witnessed in wrestling ... Competitors are very well prepared and not a bunch of morons trying to trash each other' (Cross Combat, 2004(4): 13). 
Whilst Couture and Tabbs have vested interests in portraying MMA in a socially acceptable way, it should be noted that survey data indicate that injury rates in MMA are 'similar to other combat sports, including boxing' (Bledsoe et al., 2006: 141).

The relative infrequency of deaths in MMA is perhaps even more significant. The only recorded case of death in MMA occurred in Kiev in 1998. This statistic bears little resemblance, e.g., to Ancient Greek pankration where death and serious injuries were not only common, but athletes were praised for scorning death (Poliakoff, 1987: 91). Comparison with death rates in other sports reveals the relatively 'safe' character of MMA. According to Gross (2001: 333), the death rate for boxing in the US is 0.13 per 1000 participants, compared to 0.3 in American football, 5.1 in mountaineering, and up to 12.3 in free falling parachuting and 12.8 in horse riding. By contrast there have been no deaths in MMA contests in the United States (Bledsoe et al., 2006: 140). Thus the initial 'moral panic' about MMA is based on perceived, rather than actual, levels of violence.

For these reasons, Sheard (1998a) and Howes' (1998) arguments that the development of MMA corroborates Elias's theory of civilizing processes are compeling. Sheard argues that the minority appeal of MMA relative to the pankration, (which Baker (1982) argues was the most popular event of the Ancient Greek games), the outlawing of other forms of combat sport (such as bare-knuckle fighting), and the widespread repugnance expressed towards combat sports, illustrates the greater social control over and social taboo concerning violence in contemporary societies. Howes alternatively argues that UFC organizers introduced stricter controls over violence - such as outlawing headbutts, finger breaking, hair pulling and the gouging of mouths and nostrils - in 
response to 'figurations of disapproval'. As these changes amount to 'the gradual erosion of elements that were considered "repugnant”" (Howes, 1998), UFC thus underwent a similar 'sportization' process to other modern sports. In the following section we advance and refine the interpretations offered by Sheard and Howes through the use of Wouters' concept of informalization and Elias and Dunning's quest for excitement.

\section{MMA as an Informalizing Process}

Though broadly correct, elements of both Sheard and Howes' analyses are problematic. First, since Sheard wrote MMA has maintained sufficient popular appeal to be a commercially viable televised sport. It has, moreover, become more mainstream, particularly in the United States, with Fox Sports broadcasting four documentaries about UFC champions in 2004, and Spike TV's free to air broadcasting of the reality show Ultimate Fighter in 2005. More recently mainstream sports magazines such as ESPN and Sports Illustrated have provided detailed reporting of MMA events and have featured UFC fighters on their covers (Chuck Liddell and Roger Huerta respectively). Brands such as Bud Light and Harley Davidson have become prominent sponsors of MMA events. These changes have shifted MMA from a socially marginal activity which, because many found it prepugnant, to a relatively secure and expanding modern sport.

Second, as van Bottenburg and Heilbron note, whilst Howes illustrates how stricter controls over violence became implemented in UFC, he does not explain why these activities developed in the first place, or the apparent initial de-sportizing phase. We 
suggest that informalization and the quest for excitement provide explanations for these anomolies.

Counter to certain critiques (Collins, 2005; Horne and Jary, 1987) Elias did not see civilizing processes as unilinear or evolutionary and, in his analysis of the rise of the Nazis in The Germans (1996), illustrates how decivilizing trends can become dominant thus reversing the outcome of previous civilizing patterns. Figurational sociologists have also examined apparent cases of de-civilizing of sport in this regard, notably Dunning (1986) who argued that a shift in the balance between affective and instrumental violence had occurred in post war sport in the West, Sheard (1997) who identifies the importance of cosmetic changes to the appearance of violence in sport, and Malcolm (2004) who suggests that functional democratization could lead to short term increases in violence such as those identified by van Bottenburg and Heilbron in their analysis of NHB. The value of Wouters' work, however, is that it enables us to decouple the formalizing-informalizing axis from the main civilizing-decivilizing axis. Wouters showed how civilizing processes were characterized by oscillations between formalizing (more regularized) and informalizing (more flexible application of rules and manners) trends. The latter, he notes, is apt to be misinterpreted as a de-civilizing trend, as happened in the 1960s, rather than a complex form of civilizing process, characterized by a wider variety of behaviours expressed in more moderate, flexible and controlled forms.

The more flexible application of a wider variety of combat techniques without an overall increase in the level of violence similarly suggests that the rise of MMA is indicative of an informalizing trend. The infrequency of deaths and the relatively 
limited use of more violent forms of combat in MMA provide minimal evidence of the kind of shift in habitus Elias viewed as fundamental to both (de-)sportization and (de)civilizing processes. Rather, in light of Wouters' theory of informalization, one could argue that such dangerous MMA techniques as rear naked chokes or joint locks are performed in an environment where fighters exert considerable control over the pressure and strength they apply, such that the power is sufficient to enforce a submission (the most frequent end to MMA bouts), but limited so that death does not occur. Such considerations were illustrated by former UFC champion B.J Penn who spoke of his reaction to having to release an opponent and thus surrender his dominant position at the end of a round. He explained:

I wish there had been a little more time left, but the bell sounded and I [had] got the arm bar a little too late. I had it [the arm] extended and pulled, but the round was up. I wasn't going to be unprofessional and try to hurt his arm. It would be unsportsmanlike. (Full Contact Fighter, 2002, vol 2)

Indeed in MMA texts fighters regularly talk about their 'game plans' and their 'strategy' (e.g. Snowden, 2008: 130, 211). Because the potential range of techniques which each fighter might face in MMA is greater than for fighters in non-hybrid combat forms, the degree of calculation and planning is quite marked. Frequently such considerations come back to the contrast in techniques between the respective backgrounds of the fighters, and their roots in a particular fighting discipline (Royce Gracie, cited in Snowden, 2008: 239). Though not necessarily apparent to the viewing public, testimony from contemporary participants (Wacquant, 1995) suggests that modern forms of combat are characterized by an instrumental, rather than affective, use of violence and thus by relatively high levels of self-consciousness. For instance, Frank Shamrock, 
reflecting on his preparation for a fight with ..., recalls, 'All of my techniques were designed to neutralize the ground game, close the distance on the stand-up, and fight on the inside where I knew he lacked conditioning and power' (Snowden, 2008: 125. Emphasis added).

Where Wouters' discussion of informalization involved shifting intra-societal power balances, the development of MMA entailed a more global cultural exchange. The hybridization of fighting techniques was facilitiated by their interchangeablity for, although combat sports test various skills, all have the same central goal of incapacitating an opponent. Consequently techniques from various combat sports can often be combined without fundamentally altering contests. This commingling of techniques was a consequence of the equalizing shifts in the balance of power, characteristic of the development of a more interdependent, globalized, social world. It has led, we might say, to a diminishing of contrasts in combat sport action (Maguire, 1999: 207-216). In Japan, different Eastern combat traditions (e.g. karate, kickboxing) were synthesized and packaged in accordance with the commercial practices of Western professional boxing. Here the controlled de-controlling of emotional controls was achieved through the spectacularization of events into an 'amusement park of martial arts’ (Yokohama, 2006: 182-83) which contrasted sharply with the tradition of formalism in Japanese combat sports. Concomittantly Westerners became increasingly aware of martial arts techniques and, as a consequence of the 'excitement' through deformalization that 'new' cultural practices offer, incorporated them into their existing combat events. Previous hierarchies of combat activites were challenged, especially the dominance of the amateur 'points scoring' model. Where culturally diverse techniques are combined within a single combat event, individuals inflict harm on opponents using 
an increased range of practices. The contrast between combat sports therefore diminished, while variety within each sport increased. In the absence of more widespread, structural, changes related to state formation, no marked 'de-civilizing' of habitus occurred. In this respect MMA rewarded the personality traits which Elias identified as becoming more prevalent as part of longer term civilizing processes; namely fore-thought and self-conscious reflection. The shift in the balance between externally imposed regulation and greater self-regulation is what Wouters described as an informalization process.

\section{MMA and the Quest for Excitement}

To fully account for these developments, and in response to van Bottenburg and Heilbron's contention that Howes fails to explain why MMA initially developed, it is important to recognize the sports-specific aspects of these broader processes. In this respect, the search for an appropriate tension balance in combat sports as part of the quest for excitement, provides a fuller understanding of the developmental trajectory of MMA.

Pace Elias and Dunning, pleasurable stress tensions are generated in combat sports through the performance and consumption of fighting skills. However, the sociallygenerated psychological need for stress tension exists in parallel with a relatively heightened social sensibility towards the (un)acceptable use of physical force and violence (which is contextually specific to an institutionalized activity such as sport). Thus participants and spectators have a zone with upper and lower parameters where, respectively, more intensity would cross a 'threshold of repugnance', and where less intensity would make the contest routine and dull. To be stimulating enough for 
participants and spectators, therefore, combat sports must exhibit combat intensity and remain relatively close to 'real' fighting (i.e. have or appear to have significant elements of de-controlling). Additionally, within any given society, and indeed across societies, there exist a range of perceptions as to what is 'acceptable' or not. Participants' thresholds of acceptability/desireability are invariably different to those of less involved observers. The perception of 'acceptability' which becomes socially dominant is structured by broader power relations. In this respect, activities such as Full Contact, kick boxing and MMA, have faced similar opposition to professional boxing.

There is evidence to suggest not only that proto-forms of MMA (such as HNB) were relatively violent but, as noted above, that participants actively sought heightened levels of violence in response to the relative pacification of (especially amateur) combat sports during the twentieth century. At the early stages of the aforementioned hybridization process, people with direct experience of the intense contact of combat sports started to develop mixed disciplines simply for their personal enjoyment, paying little attention to more general sensibilities or perceptions of violence. At this time considerable use of open and intense violence characterized MMA. Though these features attracted broadcasters, they were also partly hidden from the viewing public. Gentry recalls the first UFC tournament:

When Jimmerson entered the changing room, Kevin Dossier was putting his jaw in place again. It was clearly broken. Zane Frasier was in a stretcher waiting to be carried to the hospital; to the ignorance of the majority he had suffered an asthma crisis during the fight and he could not breathe without assistance ... The doctors were trying to pull out two of Tuli's teeth that had become etched in Gourdeau's foot. They decided that it would be better to 
keep the teeth inside to avoid a greater exposure of the wound during the rest of the gala (Gentry, 2004: 54).

When MMA gained greater public exposure, proponents encountered varying 'figurations of disapproval' (Howes, 1998). As Yokohama (2006) notes, despite the similar form of Japanese PRIDE and American UFC, there was relatively little criticism of the former in Japan. One might explain this with reference to the specificities of the Japanese civilizing process, the most salient feature of which has been the importance of a caste of warriors (bushi) in the country's governance (Kiku, 2004: 159). The bushi mentality, or bushido, had a significant role in the construction of Japanese national identity at the end of the nineteenth century, and permeated across social classes such that it became 'accepted as a Japanese traditional cultural trait' (Yokohama, 2006: 199). This can be seen, for instance, in the relative perceptions of violence in Japanese and American professional wrestling. In the West, however, public understanding of combat sports rested upon the dominant 'points model' used in amateur combat sports and the relatively restricted range of fighting in professional boxing. Moreover, because of the Western amateur hegemony in international sport during the twentieth century, perceptions of Eastern combat sports, would have been largely based on the stylized and dramatized combat portrayed in the the Bruce Lee inspired martial arts film genre which was part of, and contributed to, a broader perception in the west that Eastern cultures were 'almost incomprehensible’ (Kiku, 2004: 154). MMA appeared transgressive in that it was more intense than points tournaments and, in displaying a wider set of combat techniques than boxing, closer to 'real' fighting. Through its incorporation of martial arts techniques it also inherited some of the 'mysticism' (to Western eyes at least) used to market martial arts films. These factors contributed to the perception in 
the West that these combat sports were relatively violent, and hence more vociferous campaigning. For instance, Lonnie Bristol, president of the American Medical Association in the 1990s argued that:

Far from being legitimate sports events, Ultimate Fighting contest are little more than human cockfights where human gladiators battle bare-knucled until one gives up, passes out, or the carnage is stopped by a doctor or referee. The rules are designed to increase the danger to fighters and to promote injury rather than prevent it ... Ultimate Fighting contests are even more physically dangerous and morally abhorrent (than boxing), and it is the opinion of the AMA that these bloody brawls should be banned inmediately (quoted in Gentry, 2004: 109).

Senator John McCain's protest movement led 40 American states to ban UFC. Cable TV subsequently removed its support (van Bottenburg and Heilbron, 2006: 261).

Whilst this public image has, to a large extent, been maintained, it would be erroneous to treat MMA as a fixed entity. The disapproval which emerged when these activities became more publicly accessible led to various reforms which brought MMA into line with dominant social sensibilities. One example of this is the change in terminology from vale tudo or no holds barred to MMA; the latter appearing to relatively downplay violent aspects. Rules were also revised to ameliorate critics by bringing MMA within the zone of 'acceptable' tension-excitement of a greater number of people. The clearest case occurred in UFC, where weight categories, time limits, rounds, and 31 illegal actions were introduced. ${ }^{3}$ In 2001 these rules were officially sanctioned by the Athletic Commission of the State of Nevada and bouts and television coverage resumed. In Japan, where there was less violence-related criticism and no state prohibition, K-1 
underwent dual developments which impacted upon both the upper and lower thresholds of the tension balance. On the one hand, regulatory elements common in other sports forms were introduced: e.g, referees became empowered to issue fighters with a caution and warning, point reduction (where the fighter is shown a yellow card), and ultimately disqualification (where the fighter is shown a red card). Conversely regulations designed to distance $\mathrm{K}-1$ from kickboxing and thus make it more publicly appealing were introduced: e.g. the use of three rounds instead of five to make fight action more intense; the banning of 'clinches' because they were deemed to slow down the pace of the fight.

Tension balance oscillations have thus dominated the development of MMA. MMA initially underwent a swing towards de-sportization as relatively 'de-sensitized' participants sought excitement levels above the lower parameter at which activities become routine and dull. These activities infringed the higher parameter of tensionbalance for a broader public lobby which, given broader power balances, was able to exert sufficient pressure to force MMA to undergo a phase of sportization. Relatively acceptable levels of 'de-controlled' violence were settled upon, and thus a period of greater stability ensued. Similar developments seem to have occurred in the intial stages of the sportization of rugby, during which the use of boots called navvies was debated (Dunning and Sheard, 2005: 99).

\section{Spectacularization and tension balance in MMA}

Changes designed to placate MMA's critics threatened the lower parameters of the tension balance for spectators (and hence we see the countervailing developments in K1). As Sheard (1997) has noted, people's upper thresholds of tolerance can be modified 
not simply through 'real' limitations on violence, but also through 'cosmetic changes' such as the use of helmets which,

diminish the incidence of cuts, but a significant reduction on the force of the impact to the head probably does not occur ... The use of the helmet by the amateur boxer gives him a fake sense of security as it masks the effects of a hard blow to the head (Gross, 2001: 322).

Such innovations may unintentionally fail to reduce danger to participants (e.g. brain damage), but in being seen to reduce such dangers (e.g. cuts), shift the parameters of acceptability by pushing the more visible manifestations of violence 'behind the scenes' (Murphy and Sheard, 2008). Similarly people's lower thresholds can be modified through cosmetic changes which lead them to think that activities are more dangerous and less controlled than they really are. MMA promoters responded to public demands for relatively de-controlled activites by introducing 'cosmetic changes’ of this type.

Crucial in this regard are the differential perceptions of participants and audience. As van Bottenburg and Heilbron (2006: 262) note, influence over professional sport has increasingly shifted from the participants towards those watching. They further argue that this is the main factor behind the 'rise and spread' of NHB with promoters raising levels of violence in order to increase audiences and thus revenue. However, a developmental analysis suggests that MMA contests were relatively more violent in their emergent, NHB, form; that is to say, when largely driven from within the martial arts community in a search for more 'exciting' activities. Moreover, on the premise that frequency of exposure increases one's tolerance of violence, bloodshed, etc. the notion that spectators rather than competitors would be the prime movers behind the drive towards relatively more violent fight action is intuitively suspect. The work of 
Wacquant (1995), for instance, illustrates the way in which violent practices are normalized by those who regularly participate in them and how outsiders invariably have a heightened sensitivity towards, and condemn, such practices (the extensive literature of athlete pain and injury similarly illustrates this point, see e.g., Young et al. 1994; Malcolm and Sheard 2002).

Indeed the spectator survey on which van Bottenburg and Heilbron partly base their argument can be read to support this view. They found that compared to those who were themselves practitioners, martial arts 'outsiders' were more likely to be attracted to MMA due to its violence. What they do not consider, and what we suggest seems crucial, is that the perceptions of these two groups, socially constructed on the basis of their respective life experiences, are very different. Rather than making events more violent, promoters responded to the greater regulation of MMA by spectacularizing events to make them appear more violent. Whilst spectators were attracted by the 'decontrolled' appearance of MMA, explicitly claimed in the labelling of NHB, like the individualization discussed by Wouters, there is a strong illusory element which obscures the significant 'self-controlled' practice. This explains why these combat events are not viewed as especially violent by those with martial arts experience, whilst to the 'uninformed' they are. Thus in popularizing events, 'mock fights' were made to appear more 'real' through spectacularization.

Implicitly recognizing that sport's popularity is linked to the quest for excitement, MMA promoters sought to appeal to a broad public by emphasizing the de-formalized and relatively violent character of combat. When Rorion Gracie and media adsman Art Davie founded WOW Productions and collaborated with SEG enterprise to establish 
UFC, the central marketing strategy was to downplay UFC's internal regulation, and promote it as a contest without rules. This approach was underpinned by SEG programmer Campbell McLaren and UFC producer Michael Pillot's belief that, 'the best way to reach the larger audience was to sell the blood, guts and fear aspect of it' (quoted in Gentry, 2004: 64). McLaren emphasized these themes at a press conference for UFC II in 1994, stating, 'Each match will run out 'til there's a designated winner by means of knock out, surrender, doctor's intervention or death' (quoted in Gentry, 2004: 64). He further and falsely stated that UFC was banned in 49 states in an attempt to emphasize its transgressive character.

The political pressure and state regulation which followed had the intended consequence of developing regulation of the sport, but had the unintended consequence of giving MMA even greater publicity. Indeed, the antagonistic political-medical-media groups ultimately portrayed these events in exactly the way the promoters had sought to appeal to their potential customers. The greater regulation which followed from this led to the paradox of how to sell the fights as real without exposing their relatively formalized and (now) socially acceptable character. The promoters' solution was to emphasize spectacular aspects whilst reducing their stress on danger. MMA stimulated the pleasurable de-controlling of emotional controls, akin to the mimetic excitement generated by professional boxing or wrestling, but its unique selling point was the perception that it was one step closer to 'real' fighting. To do this UFC employed dramatic tools, such as wrestling in a cage instead of a ring, and representing the fighters as heroes or villains, K-1 specialized in 'revenge' matches. The spectacularization of MMA increased when Zuffa Entertainment bought UFC and introduced further changes which both increased fighter safety and spectacularized 
combat (e.g. the abolition of the original no-time rule, forcing fighters to return to their feet if they spent too long fighting on the ground).

\section{Conclusion}

We have argued that the development of MMA has not entailed a 'de-civilizing spurt' but, more accurately, can be said to exhibit the characteristics of an informalization process. The combination of an increased range of permissible combat techniques with no apparent increase in harm to participants suggests that MMA fighters exhibit a habitus characterized by significant self-regulation. It therefore appears that the violence of MMA has been exaggerated in public discourse. Invoking a longer term analysis than has hitherto been undertaken, we can see that levels of violence in MMA have changed over time as the competing interests of participants, spectators, and lobbyists have led to tension balance oscillations. Moreover, such a thesis is consistent with Elias's emphasis on the relative importance of unintended outcomes of purposive human action, and the idea that as networks of human relations become both more extensive and complex (e.g. the international development and hybridization of combat sports) the ability of any one individual or group to control developments is necessarily impaired (Elias, 1987). What is perhaps unique to MMA, on account of the particular time and space in which these combat events have developed, is the media-driven spectacularization of combat which has served to broaden the sport's appeal by ‘cosmetically’ increasing violence.

Why, if this is the case, has the development of MMA led to such public hostility? This question has implications for trends in violence in combat sports more generally. Criticism of combat events is, of course, not new. Sheard (1998b), for instance, has illustrated the medical profession's objections to boxing since the end of the nineteenth 
century leading to increasingly frequent calls to ban the sport in the early 1980s. Defenders of boxing have found the citation of comparative death rates and stress upon the instrumental and controlled aspects of fighting largely ineffectual in altering public opinion. We suggest that the public's assessment is, in fact, largely independent of such measurements of violence and relies rather more on the structural characteristics of combat events which mean that they, and by extension MMA, will always exist on the limits of socially (in)tolerable levels of violence.

The relative openness of violence is one of the primary reasons for public disapproval of combat sports. Deaths in boxing (and this was also the case with the single MMA death to date), usually occur during, or shortly after, competition. They are therefore subject to the scrutiny of an attending public and, increasingly, a mediated audience. The lead up to such events are also very different for TV cameras will witness and possibly sensationalize the violence fighters inflict on each other, possibly entailing bloodshed, bruising and knockout. By contrast, deaths in other 'high-risk' activities generally occur out of the public gaze, in remote places (e.g. in mountaineering), or with participants' faces obscured (e.g. behind the helmet of motor racing drivers). These deaths are not prefaced with what people perceive to be the signifiers of violence. Their 'behind the scenes' character is consistent, in Elias's terms, with their categorization as relatively civilized in comparison to 'de-civilized' combat sports.

In addition to this, death and injury in combat sports are generally seen as the 'natural' consequence of an activity the 'main' goal of which, critics argue, is to harm the opponent (Wacquant, 1995: 495). Participants tend not to share this perception, for the fighter's main objective is to win (usually according to the rules). Consequently the 
violence perpetrated by a fighter is rather more instrumental and rather less affective, than non-participants perceive (Dunning, 1986). Combat sports do not simply (or primarily) involve the discharge of affective violence for, just as in other sporting activities, the instrumental manifestation of violence has become increasingly significant. Boxers distinguish themselves from 'streetfighters' by their structured training and strategic planning, and because they work within a formal framework of regulation such that they stop, or are stopped, at a specific point (Wacquant, 1995). This entails the instrumental, rational and, in the Eliasian sense, 'civilized', use of violence.

If Elias and Dunning (1986) are correct, however, the popularity of combat sports rests upon the tension-excitement generated by the perception of these activities as unusual in their relatively de-controlled character. The unique combination of intentional and open conflict means that by definition combat sports exist, and will always exist, on the margins of 'real' and 'mock' fighting, and thus on the margins of modern sport. Regardless of the tangible differences between combat sports and 'real' fighting, combat sports continually 'test' the dynamic limits of social tolerance of violence because they will always be closer to 'real' fighting than other areas of social life. Moral condemnation is thus an almost inevitable reaction to the development of MMA, stemming as much from its structural properties as from its specific content. Sociologists must be cognisant of this and view public condemnation critically when considering the role of civilizing and de-civilizing processes in sport.

\section{References}


Amtmann, J.A. (2004) 'Self-reported Training Methods of Mixed Martial Artists at a Regional Reality Fighting Event', Journal of Strength and Conditioning Research 18(1), 194-96.

Baker, W. (1982) Sport in the Western World. Rowan and Littlefield: Totowa, N.J.

Beekman, S. (2006) Ringside: a History of Professional Wrestling in America. Praeger: Westport.

Bledsoe, G.H., Hsu, E.B., Grabowsky, J.G., Brill, J.D. and Li, G. (2006) ‘Incidence of Injury in Professional Mixed Martial Arts Competitions', Journal of Sport Science and Medicine 20065 (Combat Sport Special Issue): 136-142.

Bolelli, D. (2003) 'Mixed Martial Arts: a Technical Analysis of the Ultimate Fighting Championship in its Formative Years', Journal of Asian Martial Arts 12(3): 4151.

Brunekreef, W. (2007) The Golden Kyokushin and K-1 Encyclopedia. MAProductions.

Camps, H. (1990) Historia y Filosofía del Karate. Barcelona: Alas.

Collins, T. (2005) 'History, Theory and the “Civilizing Process”', Sport in History, 25(2): pp. 289-306.

Di Marino, S. (2003) Lecciones de Kickboxing. Barcelona: De Vecchi.

Dunning, E. (1986) ‘Social Bonding and Violence in Sport', in N. Elias and E. Dunning (eds) Quest for Excitement. Oxford: Basil Blackwell.

Dunning, E. and Sheard, K. (2005) Barbarians, Gentlemen and Players: A Sociological Study of the Development of Rugby Football. London: Routledge, $2^{\text {nd }}$ edition 
Elias, N. (1986) ‘An Essay on Sport and Violence’ in N. Elias, and E. Dunning, Quest for Excitement. Oxford: Basil Blackwell.

Elias, N. (1987) Involvement and Detachment. Oxford: Basil Blackwell.

Elias, N. and Dunning, E (1966) 'Dynamics of Group Sports with Special Reference to Football', British Journal of Sociology 17(4): 388-402.

Elias, N. and Dunning, E. (1986) Quest for Excitement. Oxford: Basil Blackwell.

Elias, N. (1994) The Civilizing Process, Vol 1. Oxford: Basil Blackwell.

Elias, N. (1996) The Germans. Cambridge: Polity Press.

Estwanik, J. (1995) 'Professional and Amateur Rules and Regulations', in R.C. Cantu (ed.) Boxing and Medicine. Champaign: Human Kinetics, pp. 9-16.

Fleischer, N., Andre, S., and Loubet, N. (1981) A Pictorical History of Boxing. London: Hamlym.

Fraguas, J.M. (2003) Grappling Masters. Burbank: Unique Publications.

Gentry, C. (2004) Ho Holds Barred. Reading: Milo Books.

Green T.A and Svinth, J.R (2003) 'The Circle and the Octagon: Maeda's Judo and Gracie’s Jiu-jitsu', in T.A. Green and J.R. Svinth, Martial Arts in the Modern World. London: Praeger, pp. 61-70.

Gross, L. (2001) ‘Boxing’, in F.H. Fu and D.A Stone (eds) Sport Injuries. Philadelphia: Lippincott Williams and Wilkins, pp. 320-51

Hlinak, M. (2009) 'Judo Comes to California: Judo vs Wrestling in the American West, 1900-1920’, Journal of Asian Martial Arts, 18(2): 8-19. 
Horne, J. and Jary, D. (1987) 'The Figurational Sociology of Sport and Leisure of Elias and Dunning: an Exposition and Critique', in J. Horne, D. Jary and A. Tomlinson (eds), Sport, Leisure and Social Relations (Sociological Review Monograph 33) London and New York: Routledge \& Kegan Paul, pp. 86-112.

Howes, M. (1998) 'The Civilizing of the Ultimate Fighting Challenge'. Unpublished BSc dissertation, Aberdeen University.

Kent, G. (1969) A Pictorial History of Wrestling. London: Spring Books.

Kerr, J. (2005) Rethinking Aggression and Violence in Sport. London: Routledge.

Kiku, K. (2004) ‘The Development of Sport in Japan', in E. Dunning, D. Malcolm and I. Waddington (eds) Sport Histories: Figurational Studies in the Development of Modern Sports. London: Routledge, pp. 153-171.

Law, M. (2008) The Pyjama Game: a Journey into Judo. London: Aurum Press.

Maguire, J. (1999) Global Sport: Identities, Societies, Civilizations. Cambridge: Polity Press.

Malcolm, D. and Sheard, K. (2002) “"Pain in the Assets”: The Effects of Commercialization and Professionalization on the Management of Injury in English Rugby Union’, Sociology of Sport Journal, 2002, 19(2): 149-169.

Malcolm, D. (2004) 'Cricket: Civilizing and De-civilizing Processes in the Imperial Game’, in E. Dunning, D. Malcolm and I. Waddington (eds) Sport Histories: Figurational Studies of the Development of Modern Sports. London: Routledge, pp. 71-87. 
Malcolm, D. (2005) 'The Emergence, Codification and Diffusion of Sport: Theoretical and Conceptual Issues', International Review for the Sociology of Sport 2005, 40(1), 115-118.

Murphy, P. and Sheard, K. (2008), 'Boxing Blind: Unplanned Processes in the development of modern boxing', in D. Malcolm and I. Waddington (eds), Matters of Sport: Essays in Honour of Eric Dunning. London: Routledge, pp. 40-56.

Poliakoff, M.B. (1987) Combat Sports in the Ancient World. New Haven: Yale University Press.

Perreca, G. and Malori, D. (2000a) Full Contact. Madrid: Tutor.

Perreca, G. and Malori, D. (2000b) Kickboxing. Madrid: Tutor.

Sánchez García, R. (2006) ‘Paradigma Cultural y Violencia en la Sociedad Española: El caso de los Deportes de Combate en la Comunidad de Madrid’. Unpublished PhD Thesis.

Sheard, K. (1992) 'Boxing in the Civilizing Process’ Unpublished PhD thesis, CNAA.

Sheard, K. (1997) 'Aspects of boxing in the western “civilizing process”, International Review for the Sociology of Sport 32(1): 31-57.

Sheard, K. (1998a) ‘Book Review: John Sugden, Boxing and Society: an International Analysis', The Sports Historian 17(1):216-219.

Sheard, K.G. (1998b) 'Brutal and Degrading: the Medical Profession and Boxing', International Journal of the History of Sport 15(3): 74-102.

Snowden, J. (2008). Total MMA. Inside Ultimate Fighting. Toronto. ECW Press. 
Sugden, J. (1996) Boxing and Society. Manchester: Manchester University Press.

Svinth, J.R. (2003b) 'The Spirit of Manliness: Boxing in Imperial Japan, 1868-1945’, in T.A. Green and J.R. Svinth (eds) Martial Arts in the Modern World. London: Praeger, pp.37-46.

Svinth, J.R. (2003a) 'Kendo in North America: 1885-1955’, T.A. Green and J.R. Svinth (eds) Martial Arts in the Modern World. London: Praeger, pp. 149-166.

Van Bottenburg, M. and Heilbron, J. (1997) 'The Brutalization of Fighting Contests’, paper presented at the Norbert Elias Memorial, Amsterdam.

Van Bottenburg, M. and Heilbron, J. (2006). 'De-Sportization of Fighting Contests: The Origins and Dynamics of No Holds Barred Events and the Theory of Sportization', International Review for the Sociology of Sport 41(3-4): 259-282.

Wacquant, L. (1995) 'The Pugilistic Point of View: How Boxers Think and Feel about their Trade?', Theory and Society 24: 489-535.

Wouters, C. (1986) 'Formalization and Informalization: Changing Tension Balance in Civilizing Processes’, Theory, Culture and Society 3(2): 1-18.

Wouters, C. (2004) 'Changing Regimes of Manners and Emotions: from Disciplining to Informalising', in S. Loyal and S. Quilley (eds) The Sociology of Norbert Elias. Cambridge: Cambridge University Press, pp. 193-211.

Yokoyama, K. (2006) A Sociohistorical Analysis of Violent Sports in Japan with Particular Reference to the Theory of Civilizing Process. Unpublished PhD, Brighton University. 
Young, K. White, P, and McTeer, W., (1994) 'Body Talk: Male Athletes Reflect on Sport, Injury and Pain’, Sociology of Sport Journal, 11(2), 175-94. 
Table 1. MMA participation in Europe

$\begin{array}{lcc}\text { Country } & \text { Participants } & \text { International Fighters } \\ \text { Russia } & 50,000 & 120 \\ \text { Holland } & 17,000 & 70 \\ \text { England } & 15,000 & 40 \\ \text { Germany } & 12,000 & 15 \\ \text { Ukraine } & 11,000 & 50 \\ \text { Italy } & 10,000 & 12 \\ \text { France } & 8,000 & 35 \\ \text { Spain } & 6,000 & 10 \\ \text { Belgium } & 5,000 & 12 \\ \text { Sweden } & 2,000 & 15 \\ \text { Croatia } & 1,000 & 10\end{array}$

Source: Fightsport (2004(3): 26-27)

\section{Notes}

1 See www.grupochuteboxe.com, www.tqfc.com, www.braziliantopteam.com.

2 From UFC15, fighters were prohibited from kicking an opponent on the ground, or kneeing the face of a grounded opponent.

3 See http://www.ufc.com/index.cfm?fa=LearnUFC.Rules 